Brit. J. industr. Med., 1947, 4, 30.

\title{
THE CONTROL AND ELIMINATION OF SILICOSIS IN THE WEST COAST HAEMATITE IRON ORE INDUSTRY*
}

\author{
BY \\ JOHN CRAW \\ Whitehaven, Cumberland \\ (RECEIVED FOR PUBLICATION, FEBRUARY 24, 1946)
}

\begin{abstract}
Introduction
The history of haematite iron ore mining in the Cumberland and Furness districts has been excellently described by Kendall (1893), and from a summary of this and works by Smith (1924), the following brief facts have been taken.
\end{abstract}

The date of the first working of haematite in Cumberland and Furness is uncertain, but the exposed veins in the Lake District must have been known long before the concealed bodies were discovered. The Furness ore appears to have been known to the ancient Britons, for, some time ago, polished celts were found in old workings at Stainton. That the Romans worked iron ore in Cumberland and Furness is probable. Numerous heaps of cinders found in Furness have been attributed to the Roman period, but some authorities attribute them to the Norsemen. The earliest account dealing with Cumberland is of mining at Bigrigg in 1179, and at this time a forge was set up, but it was not until the eighteenth century that ore was produced in any quantity, although constant mining was in progress until 1701 at Bigrigg, and even in 1694 the ore was being shipped via Whitehaven to the Forest of Dean. In 1816 mining was almost discontinued, but the Bigrigg mines were re-opened in 1825 . From the accounts of Fell (1908), the monks dug their ore from trenches, but towards the end of the fourteenth century mining came into practice. Pumps were installed in 1721, and in 1840 a steam engine was used. The ordinary tools employed by the miner were the pick, the gad, and the spade, which even as late as the first half of the nineteenth century were wooden and shod with iron. The hammer and jumper method was the regulation method of drilling from early times until 1913. In 1913 the pneumatic drill, afterwards known as the dry drill type, was introduced, and was in universal use until about 1925, when the wet drill was first used at Florence Mines, and gradually came into

\footnotetext{
* Based on a paper read to the Association of Industrial Medical Officers at the London School of Hygiene and Tropical Medicine on December 14, 1945 .
}

general use in the ore field. Concurrently with the introduction of wet drills, considerable attention was paid to improving ventilation, and exhaust fans were installed. A further technical advance in allaying the dust after blasting was made through the introduction and development of the mist projector in 1935.

Before the introduction of pneumatic drills it was traditionally believed, amongst both laymen and the medical profession, that haematite iron ore mining was a very healthy occupation. After the introduction of pneumatic drills in 1913 all the evils which occurred were attributed to their use. Notwithstanding the tradition, Collis (1923) made the suggestive observations that in 1910 the haematite miners of Cumberland and Lancashire contrasted with all other ironstone miners in the country, in showing not only a higher mortality from phthisis and other pulmonary diseases, but also a maximum mortality from phthisis at a later age period.

Cronin (1926), after an investigation, including the inspection of four mines and the examination and interrogation of 100 drillers, pointed out some highly unsatisfactory features. He drew attention to the dustiness of the working places, and to the frequent lack of ventilation at the working faces. He showed that a percentage of the men became short of breath after working for long periods in the mines, and concluded that the inhalation of haematite dust produces certain changes in the lungs which are diffuse and not localized and which affect the apices more than the bases. He added that 'the changes do not give rise to the pulmonary diseasesi.e. asthma, bronchitis, pneumonia, and phthisiswhich commonly result from dust inhalation.' In 1933 the 'Committee on Industrial Pulmonary Disease' of the Medical Research Council issued a report with the following conclusions:

1. A certain proportion of haematite miners suffer from a form of pneumoconiosis caused by the inhalation of mine dust containing both finely divided haematite and silica. There appears to be a notable pre- 
disposition to the development of tuberculosis, and in some cases the disease causes disablement and death.

2. The disease presents definite characteristics, so that it can be recognized on clinical and radiological grounds during life, and by post-mortem examination of the lungs in fatal cases.

3. There was not sufficient evidence to enable the Committee to say what part, if any, was played by the haematite present in the dust, but, in view of the geological evidence, they considered that silica was invariably present in the mine dust and may be inhaled to such an extent as to cause fibrosis of the lungs. In this connexion it appeared to them to be consistent with the evidence and the present nomenclature to describe the disease as a form of silicosis, that is, fibrosis of the lungs due to silica dust.

4. The evidence pointed to a risk being associated with the employment of machine drilling, but the Committee did not feel that other workers underground, though not so employed, could be regarded as free from risk.

5. Lastly, the Committee, regarding the dust produced in haematite mines as dangerous, recommended that due consideration be given to measures for suppressing the dust in these mines.

When it was realized that there was a risk to health and life in the processes of haematite mining, the management were very soon investigating the facts and considering means of improving conditions. Wet drills had already been introduced into the Florence and Ullcoats mines, and these were soon adopted by other companies. At the same time the manager of the Florence and Ullcoats mines was spending much time and thought on the question of dust suppression after blasting. In 1934 a scheme was conceived for the closest co-operation between mining and medical control in order to improve the health of the industry. The three largest mining concerns formed a small company to control this work, and I was appointed medical director. A house was purchased in Whitehaven and equipped with a large $x$-ray and clinical room with a modern high power $x$-ray plant that can take chest radiographs at a distance of 6 feet and with an exposure of a 1/20th of a second; a large waiting room; a fully equipped laboratory, both clinical and pathological, in which the routine and research studies are carried out; an office and filing room so that consecutive yearly records can be kept of each workman.

In 1935 the Silicosis Act came into being for the haematite iron ore mining industry. The country was still in a state of industrial depression, and there was much under-nourishment in the Egremont district. The managements decided to make examination of all workmen entering the industry compulsory.

\section{The Problems}

Three main policies were decided on: (1) the selection of men suitable for work underground; (2) the institution and maintenance of optimum working conditions underground; and (3) medical supervision of selected workmen.

A long-term investigation was also started on the significance and magnitude of the problem of pneumoconiosis.

\section{Estimation of the Hazard}

The haematite mines of the north-west coast comprise three separate and distinct groups: (a) the Egremont district in West Cumberland, which now extends between Cleator Moor (three miles east of Whitehaven) and Haile (two miles south-east of Egremont); (b) the Hodbarrow mines near Millom; and $(c)$ the Furness district. The haematite iron ores occur in the carboniferous limestone. The bodies vary in shape and size; the majority are connected with faulting. The mines still operating are working fairly large, irregularly shaped masses.

From the point of view of the incidence of silicosis the ore is of two distinct types. (a) Compact, hard, massive, brownish-red or purple to bluish-grey ore, varying considerably in hardness, is the predominating type found in the Egremont district. (b) Soft, dull, reddish-purple ore is the main type found in the Hodbarrow mines and Furness district.

The working conditions vary considerably according to the hardness of the ore, which governs the type and use of pneumatic drills, and also the quantity of explosives necessary per ton of ore mined, which in turn is correlated to the amount of dust produced.

By the examination of chemical analysis of haematite ores during the last 50 years, it was ascertained that the better class ores usually contain about 7 per cent. insoluble residues, but this percentage may rise to 20 . The washed residue of all haematite ores after the iron has been digested with $\mathrm{HCl}$ shows a large preponderance of quartz, with a small amount of amorphous silicate of alumina, and on rare occasions an almost infinitesimal amount of silicate of iron.

\section{Mining Conditions and Radiological Findings in Miners' Lungs before 1935}

The mining conditions in most mines before 1935 were characterized by an all-pervading dustiness in the underground workings. Some of the mines, which have now been closed, were undoubtedly badly 


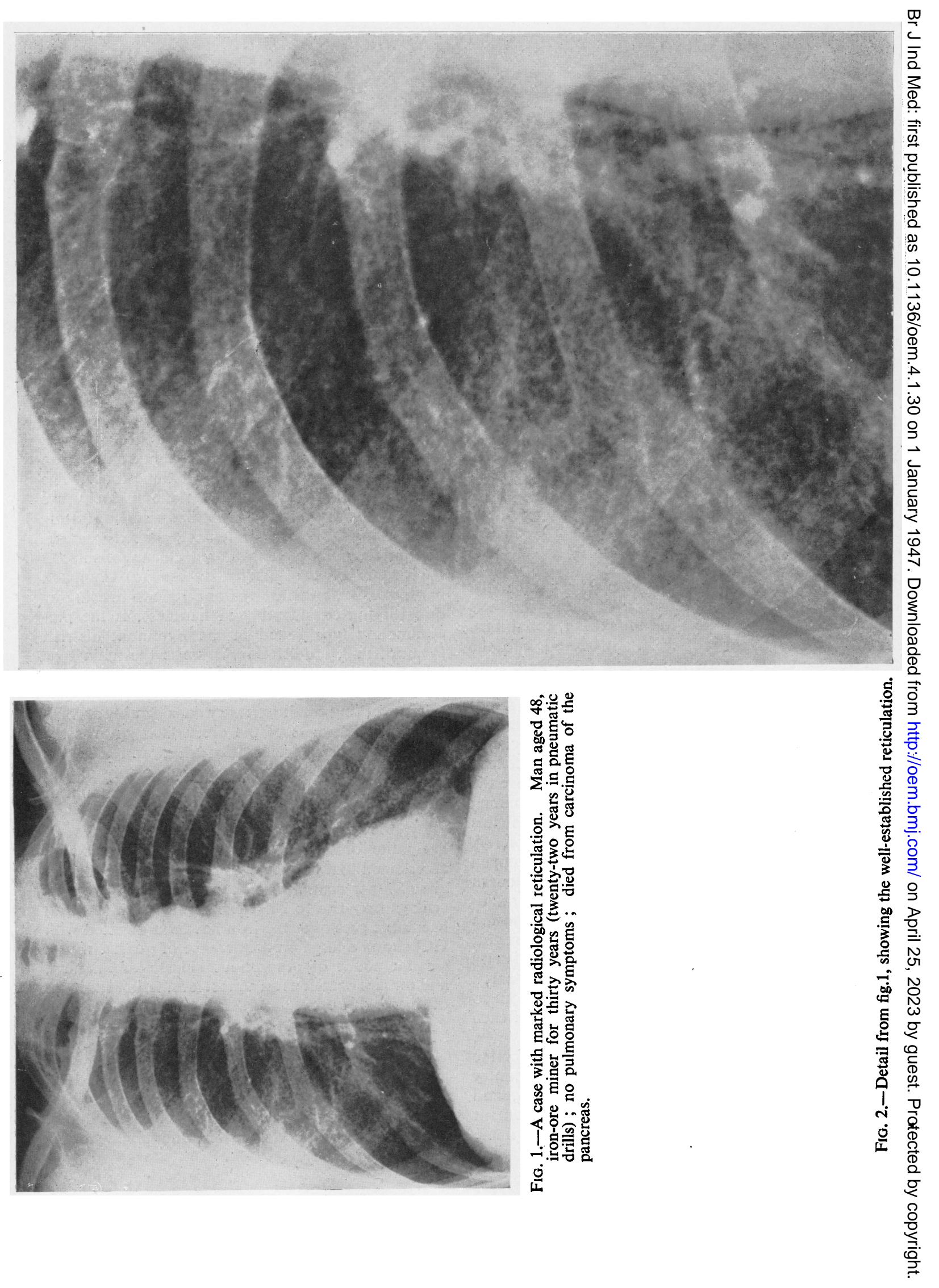




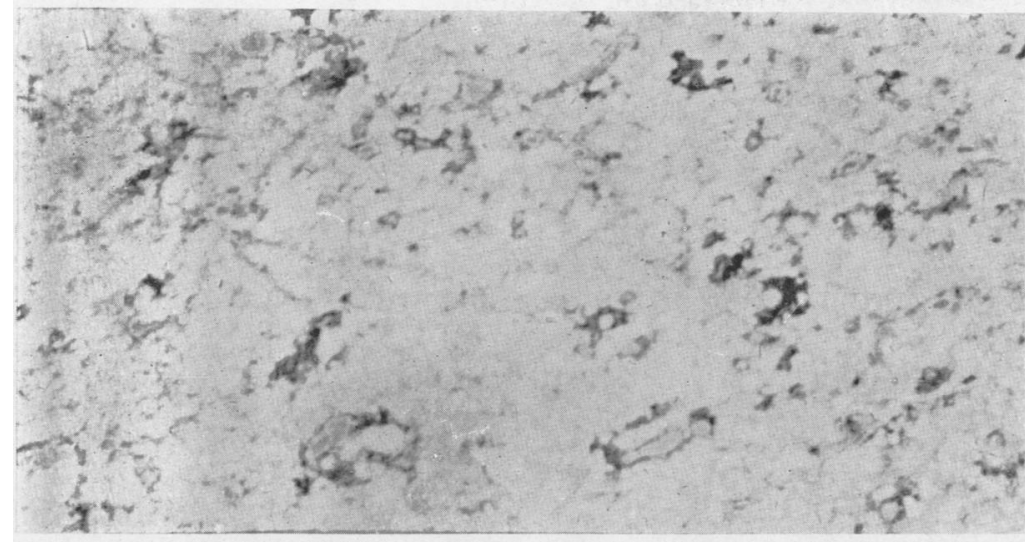

FIG. 3.--Section of the lung shown in fig. 1 ; note the typical appearances of small, irregular-shaped nodules due to linear accumulation of dust. $(\times 15$.

An opportunity presented itself to examine a fairly large group of underground workers who had spent all their working life in haematite mines under the conditions that existed before 1935, but before analysing the findings it is necessary to explain the radiological changes that occur in the lungs of haematite miners as a result of inhaling the dust in which they worked.

\section{Radiological Changes and Pathological Anatomy}

Iron casts a very dense radiological shadow, and if haematite is radiographed side by ventilated, and the temperature at the working face sometimes rose as high as $90^{\circ} \mathrm{F}$. Dust was inhaled in large quantities, and the miners were constantly ' hawking and spitting.' On various occasions a dust count specimen taken under the old working conditions revealed particles heaped up on the slide and quite uncountable. The total number of particles must have been many millions per $\mathrm{c.cm}$.

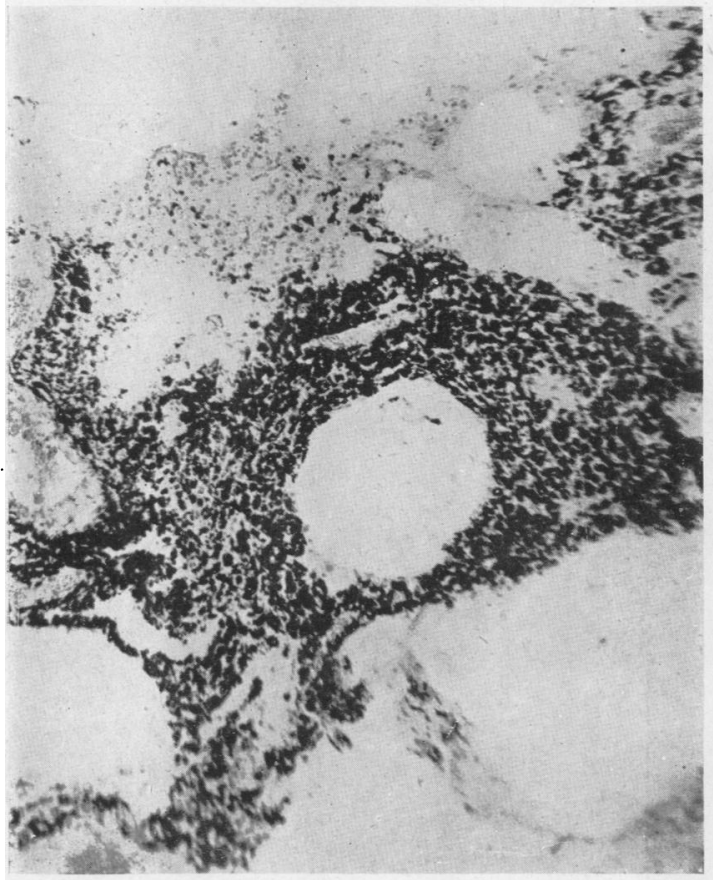

FIG. 4A.-Nodule from the specimen in fig. 3. Ordinary staining. side with an equal bulk of coal dust it is shown to possess 4.5 times the radiological density. This fact should always be remembered in comparing the shadows seen in the radiograph of an iron ore miner's chest and, for example, a coal miner's. With this reservation a classification has been formulated of the same general type as was followed by Hart and others (1942) in their report on

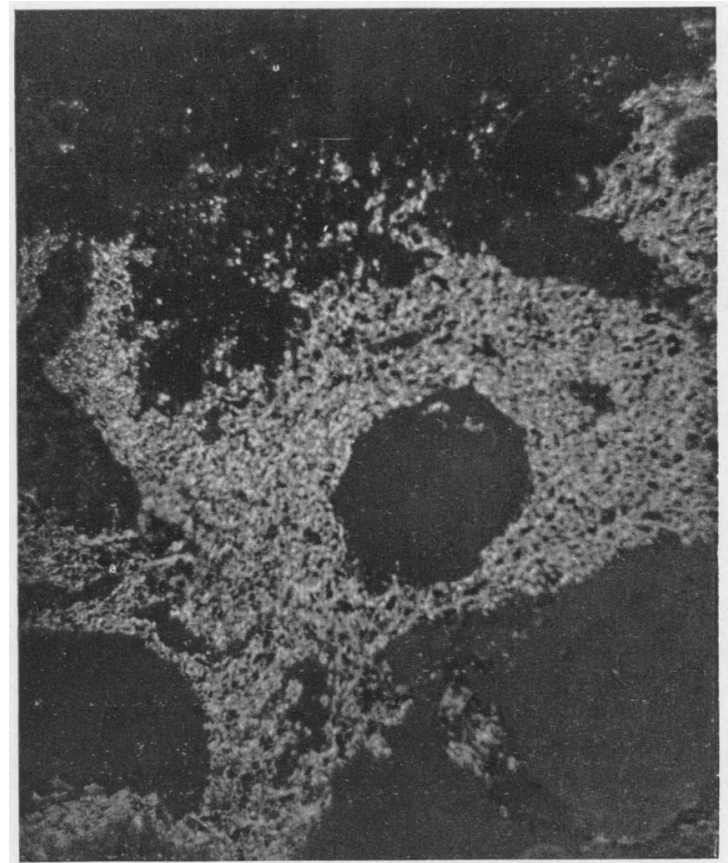

FIG. 4B.--The same section under dark-ground illumination. 


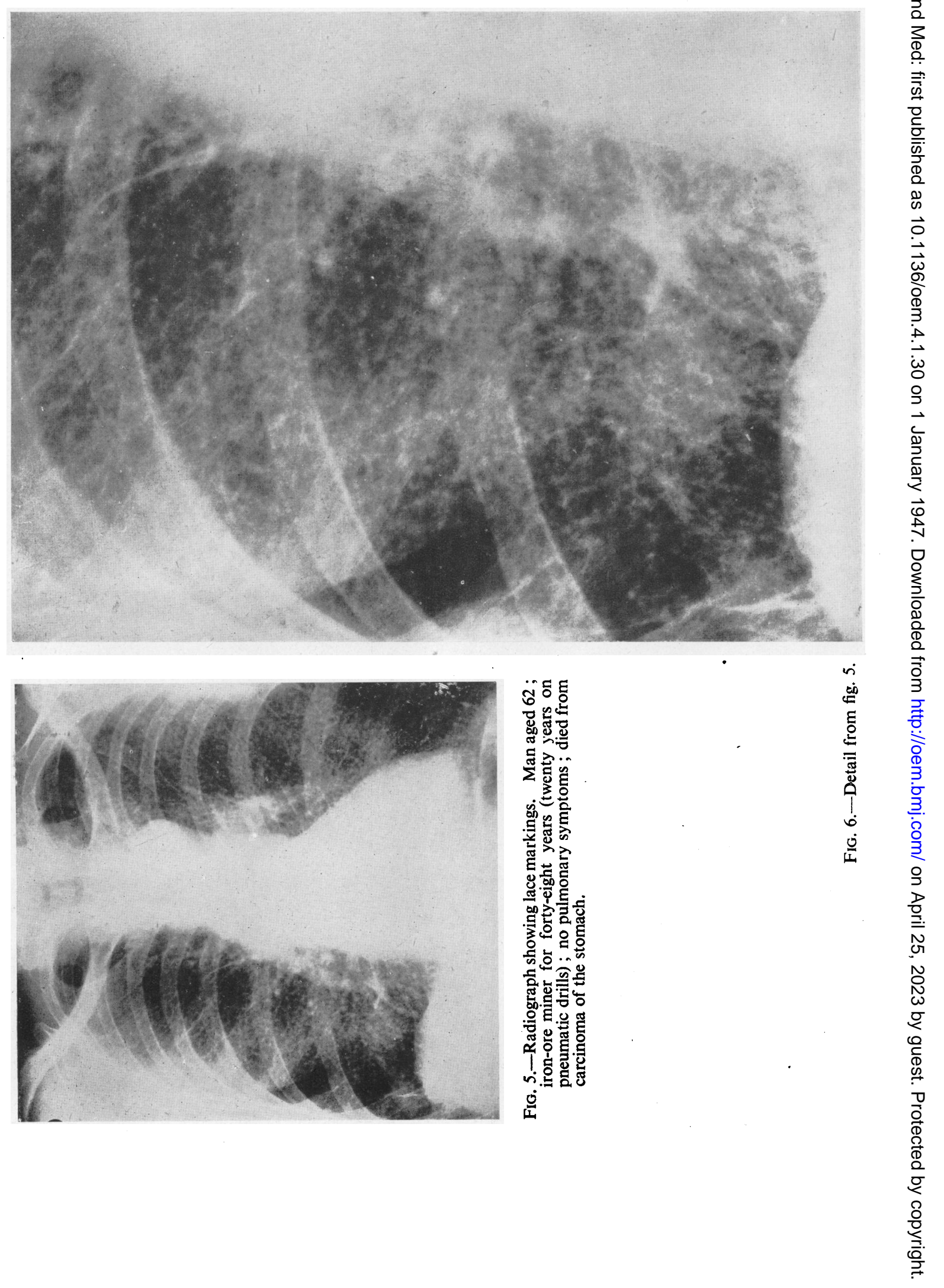


chronic pulmonary disease in South Wales coal miners.

The following facts are from the findings at necropsies performed in the last 10 years, and show that the $x$-ray shadows conform accurately to the pathological anatomy. It is found convenient to classify the radiological types as follows: (1) normal; (2) exaggerated linear markings; (3) radiological reticulations; (4) radiological nodulation; (5) massive shadows.

2. Exaggerated Linear Markings.-The shadows have no differentiating features from numerous other conditions causing exaggeration of the normal vascular markings.

3. Radiological Reticulation.-There are two distinct types: (a) reticulation proper, and $(b)$ lace markings.

(a) Reticulation proper may vary from exceedingly fine to coarse, and the shadows have a striking resemblance to miliary tuberculosis in its varying phases. Fig. 1 is the radiograph of such a case; fig. 2 is a contact print showing well established radiographic reticulation. The cut surface of the lung is usually a dull brown colour, but may be grey if the amount of dust is not great. No nodulation or linear fibrosis is either palpable or visible, nor is there any nodulation or even firmness palpable or visible under the pleura. Fig. 3 shows an ordinary section $(\times 15)$ with the typical appearances of small irregular-shaped nodules about $\frac{1}{2} \mathrm{~mm}$. in size due to linear accumulations of dust. All these are in perivascular locations. There is no evidence of collagen formation, and diligent search after Wilder's reticulin stain shows either none or very sparse amount of reticulin fibres. There is plenty of particulate dust, especially haematite. Fig. 4A shows a nodule with ordinary staining, fig. 4B is the same section under dark-ground illumination. These illustrations show that almost the entire structure is particulate haematite and silica. The pathological entity is the same in fine and coarse radiological reticulation, the variation being only in degree.

The chemical analysis of the lung shown in fig. 1 showed: percentage silica to lung 0.95 ; percentage silica to ash 6.3 ; percentage $\mathrm{Fe}_{2} \mathrm{O}_{3}$ to lung 7.7; percentage $\mathrm{Fe}_{2} \mathrm{O}_{3}$ to ash 50 ; total silica $2.35 \mathrm{~g}$.

(b) Lace markings. - This type of radiological reticulation is rare. The shadows are very heavy and dense, giving the appearance of an interwoven linear pattern, the striae being of equal thickness throughout. Fig. 5 is a radiograph from such a case, and Fig. 6 a contact print. Again the cut surface shows no visible or palpable nodulation or other fibrosis-only linear arrangement of the dust with concentrated deposits. Such dust accumulation

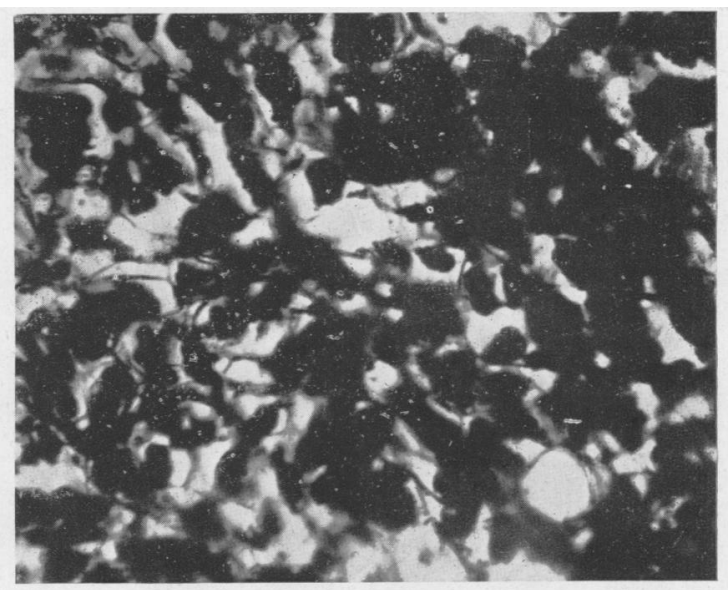

FIG. 7.-Dust accumulation, showing reticulation : same case as fig. 5. Wilder's reticulation stain.

when stained with Wilder's reticulin stain shows definite reticulation (fig. 7). The silica and iron content of this lung was very high.

The chemical analysis of the lung shown in fig. 5 showed: percentage silica to lung 1.9; percentage silica to ash 8; percentage $\mathrm{Fe}_{2} \mathrm{O}_{3}$ to lung 12; percentage $\mathrm{Fe}_{2} \mathrm{O}_{3}$ to ash 49 ; total silica $4 \cdot 8 \mathrm{~g}$.

3. Radiological Nodulation.-Nodulation of a size of about $2 \mathrm{~mm}$. is relatively uncommon when there are no associated conglomerate masses. A certain number do occur, and they are always in association with radiological reticulation. Radiologically the nodules are without clear-cut edges, and the consistency of the shadow varies within the nodule. Fig. 8 shows the radiograph of such a case, and fig. 9 a contact print. The cut surface of the lung is characteristic. The lung substance is either normal or very slightly brown-stained, and dotted over the surface are areas of brownish or reddishbrown nodules. They look and feel slightly raised above the surface, and are slightly more resistant to touch than the intervening lung tissue (fig. 10). Fig. 11 shows a typical nodule (this case died of peritonitis and had a terminal pneumonia). It is seen to have irregular edges and not to be compact. The nodule is formed of particulate silica and haematite enmeshed in sparse immature collagen.

The chemical analysis of the lung shown in fig. 8 showed: percentage silica to lung 1.03 ; percentage silica to ash 7.2; percentage $\mathrm{Fe}_{2} \mathrm{O}_{3}$ to lung 6.56; percentage $\mathrm{Fe}_{2} \mathrm{O}_{3}$ to ash 46 .

Pathological Anatomy of Conglomerate Fibrosis

The pathological anatomy of conglomerate fibrosis is similar to the massive fibrosis seen in all 

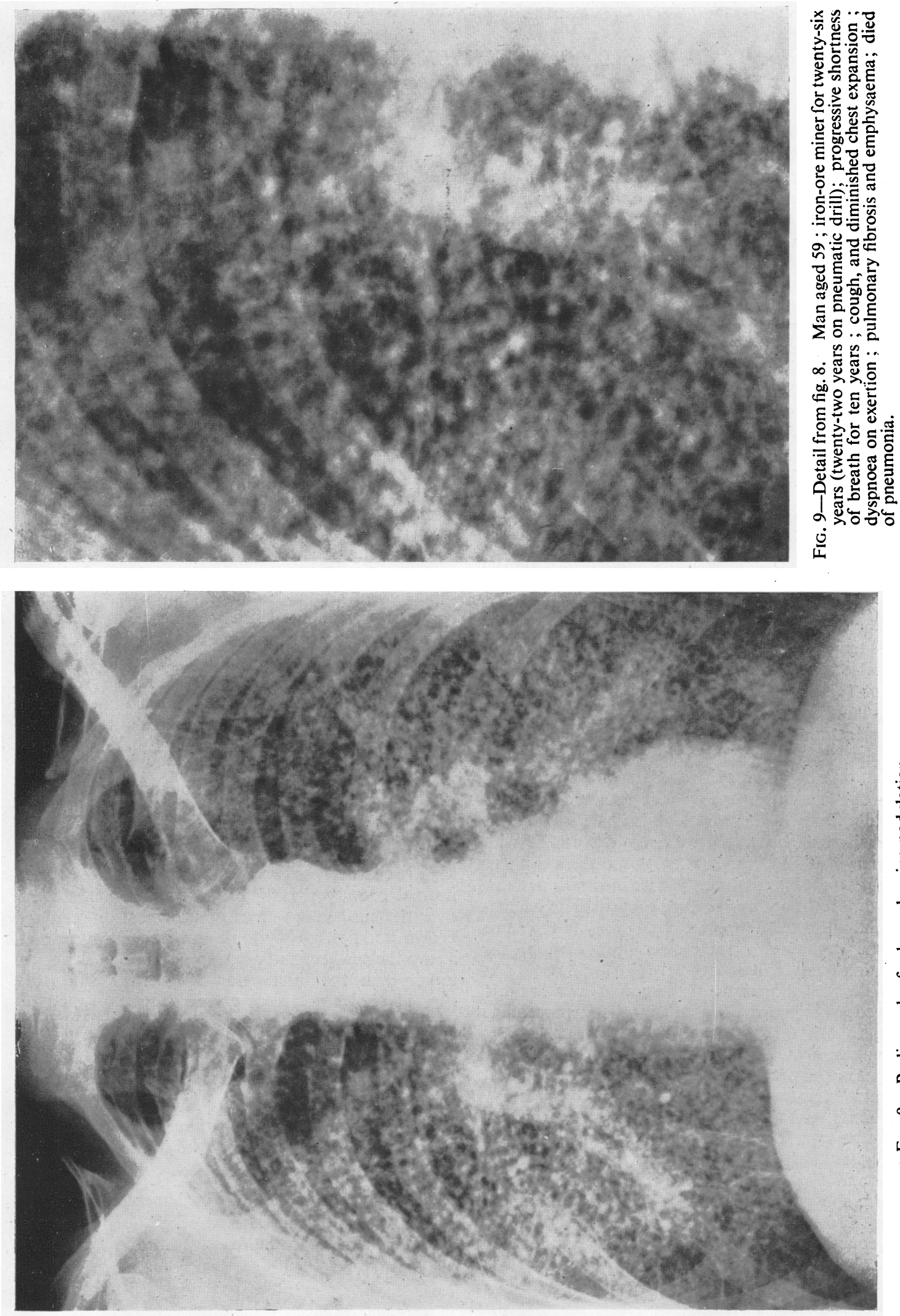


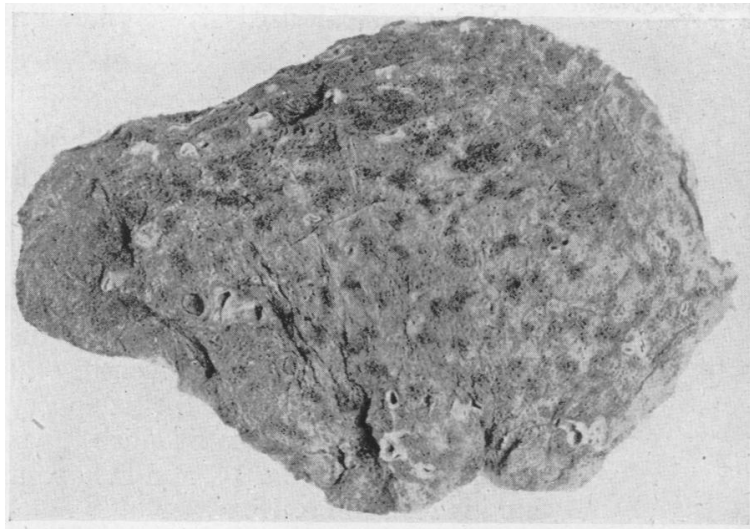

Fig. 10.-Lung of case radiographed in figs. 8 and 9 .

silicosis due to mixed dusts. At necropsy 75 per cent. of these cases have shown conclusive evidence of tuberculous infection.

1. The massive type of lesion is most marked in the upper half of both lungs. The areas are completely airless and excessively hard, often with sharply defined margins. The colour is brick red. The less fibrosed area is chiefly basal, and is tough rather than hard and often emphysematous; bullae are frequently present. Fig. 12 shows the radiograph of a lung of this type, and fig. 13 the actual lung.

2. The diffuse type of lesion is more uniform in appearance. The whole organ is brick red and

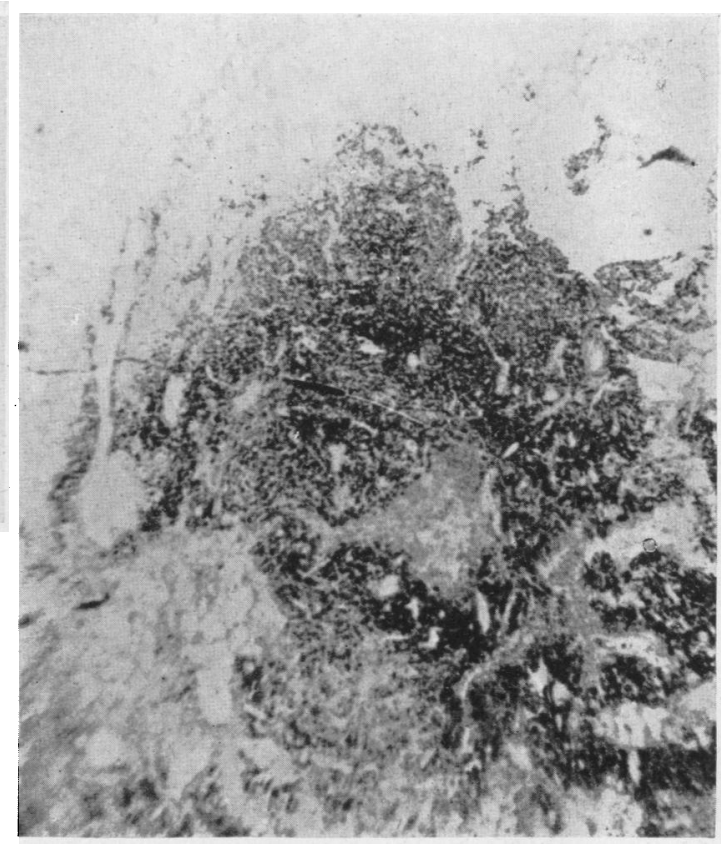

Fig. 11.-A typical nodule from the lung shown in fig. 10.

obviously fibrosed, with a co!our less brilliant and not so hard, and is also emphysematous.

3. The nodular type of lesion co-exists with massive lesions, and it is interesting to note that nodules of some size always co-exist with active tuberculosis.

TABLE 1

PERCENTAGE INCIDENCE, ACCORDING TO LENGTH OF SERVICE UNDERGROUND, OF RADIOLOGICAL ABNORMALITIES IN 191 MEN

\begin{tabular}{|c|c|c|c|c|c|c|c|c|c|c|c|c|}
\hline \multirow{3}{*}{ Radiological classification } & \multicolumn{12}{|c|}{ Number of years undergound } \\
\hline & \multicolumn{2}{|c|}{ less than 10} & \multicolumn{2}{|c|}{$10-20$} & \multicolumn{2}{|c|}{$20-30$} & \multicolumn{2}{|c|}{$30-40$} & \multicolumn{2}{|c|}{$43+$} & \multicolumn{2}{|c|}{ Total } \\
\hline & No. & $\begin{array}{c}\text { per } \\
\text { cent. }\end{array}$ & No. & $\begin{array}{c}\text { per } \\
\text { cent. }\end{array}$ & No. & $\begin{array}{c}\text { per } \\
\text { cent. }\end{array}$ & No. & $\begin{array}{c}\text { per } \\
\text { cent. }\end{array}$ & No. & $\begin{array}{c}\text { per } \\
\text { cent. }\end{array}$ & No. & $\begin{array}{l}\text { per } \\
\text { cent. }\end{array}$ \\
\hline Normal & 44 & $89 \cdot 6$ & 47 & $70 \cdot 2$ & 24 & $53 \cdot 3$ & 7 & 35 & 1 & 10 & 123 & $64 \cdot 5$ \\
\hline Reticulation & 3 & $6 \cdot 2$ & 16 & $23 \cdot 9$ & 19 & $42 \cdot 3$ & 9 & 45 & 2 & 20 & 49 & $25 \cdot 4$ \\
\hline Nodulation .. & 0 & & 0 & & 0 & & 2 & 10 & 0 & & 2 & $1 \cdot 1$ \\
\hline Massive consolidation & 0 & & 1 & $1 \cdot 5$ & 1 & $2 \cdot 2$ & 2 & 10 & 7 & 70 & 11 & $5 \cdot 8$ \\
\hline $\begin{array}{ccc}\text { Other conditions, } & \text { including } \\
\text { tuberculosis } & . . & .\end{array}$ & 2 & $4 \cdot 2$ & 3 & $4 \cdot 5$ & 1 & $2 \cdot 2$ & 0 & & 0 & & 6 & $3 \cdot 2$ \\
\hline $\begin{array}{lll}\text { Average age. } & . . & \\
\end{array}$ & \multicolumn{2}{|c|}{28} & \multicolumn{2}{|c|}{$36 \cdot 5$} & \multicolumn{2}{|c|}{$43 \cdot 5$} & \multicolumn{2}{|c|}{52} & \multicolumn{2}{|c|}{61} & & \\
\hline Average years underground & \multicolumn{2}{|c|}{$5 \cdot 4$} & \multicolumn{2}{|c|}{$14 \cdot 8$} & \multicolumn{2}{|c|}{$23 \cdot 3$} & \multicolumn{2}{|c|}{$33 \cdot 3$} & \multicolumn{2}{|c|}{44} & & \\
\hline
\end{tabular}




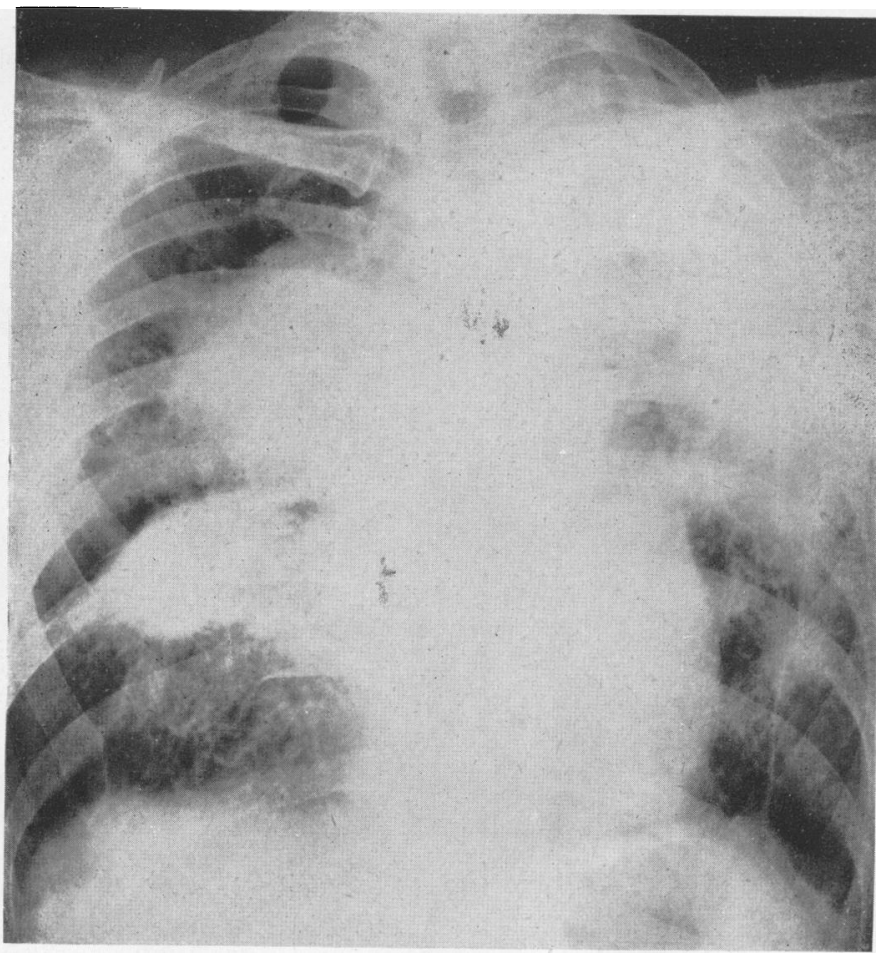

Fig. 12.-Radiograph of a lung with a massive lesion. Man aged 53 ; iron-ore miner for thirty-two years (twenty-one years on pneumatic drills); progressive shortness of breath for ten years after pneumonia; cough and expectoration with marked dyspnoea; died from advanced silicosis.

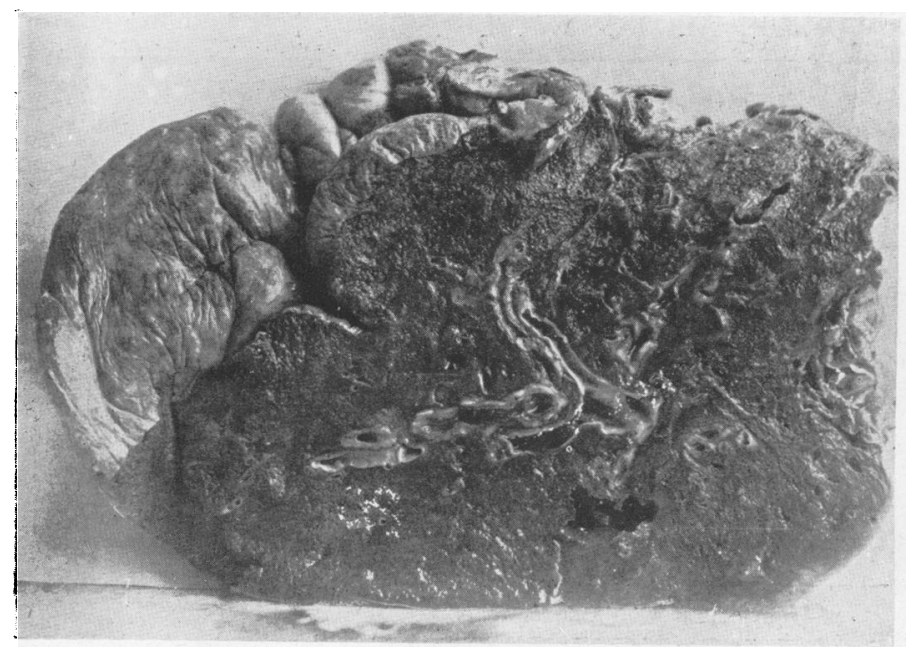

FIG. 13.-The lung radiographed in fig. 12.
The chemical analysis of the lung illustrated in fig. 13 showed: percentage silica to lung $1 \cdot 14$; percentage silica to ash $7 \cdot 1$; percentage $\mathrm{Fe}_{2} \mathrm{O}_{3}$ to lung $6 \cdot 8$; percentage $\mathrm{Fe}_{2} \mathrm{O}_{3}$ to ash 40 .

In the aerated lung classical nodules are found and they are present only with active tuberculosis. In the fibro-caseous masses there is nodulation of a closely packed type, and each nodule has a structureless caseous centre with haematite and silica at the periphery. A radiograph of a case of silico-tuberculosis is seen in fig. 14, and the actual lung is seen in fig. 15.

An opportunity was taken to examine two distinct groups of miners, one group from the Egremont district in 1935, and another group from a mine in the Furness district in 1940. The Egremont district group comprised 191 men who had spent their entire working life in these mines, and who were either actually working as miners at that time, or had done so until a short time before the examination. It was impossible to separate the men into drillers and non-drillers, as most men graduated from labourer to full miner in the course of years-sometimes after only two or three years.

Table 1 shows the $x$-ray classification of underground workers according to the length of service in the process.

It will be seen from the table that, under old conditions of mining, progressive changes took place in the miners' lungs. Of 49 men who had served for less than 10 years underground, $89 \cdot 6$ per cent. had normal radiographs, $\mathbf{6 \cdot 2}$ per cent. showed the condition of reticulation, $\mathbf{4} \cdot \mathbf{2}$ per cent. showed other changes, actually evidence of healed tuberculous infection. As the number of working years increased, each class showed a progressively smaller percentage of normal lungs. The total number of men over 40 included in the table is very small, but only 1 out of 10 had a normal chest, and 7 , or 70 per cent. showed evidence of massive changes. In all, the biggest percentage of abnormal radiological findings was of the reticulation type, the type presenting the most difficult problem. 

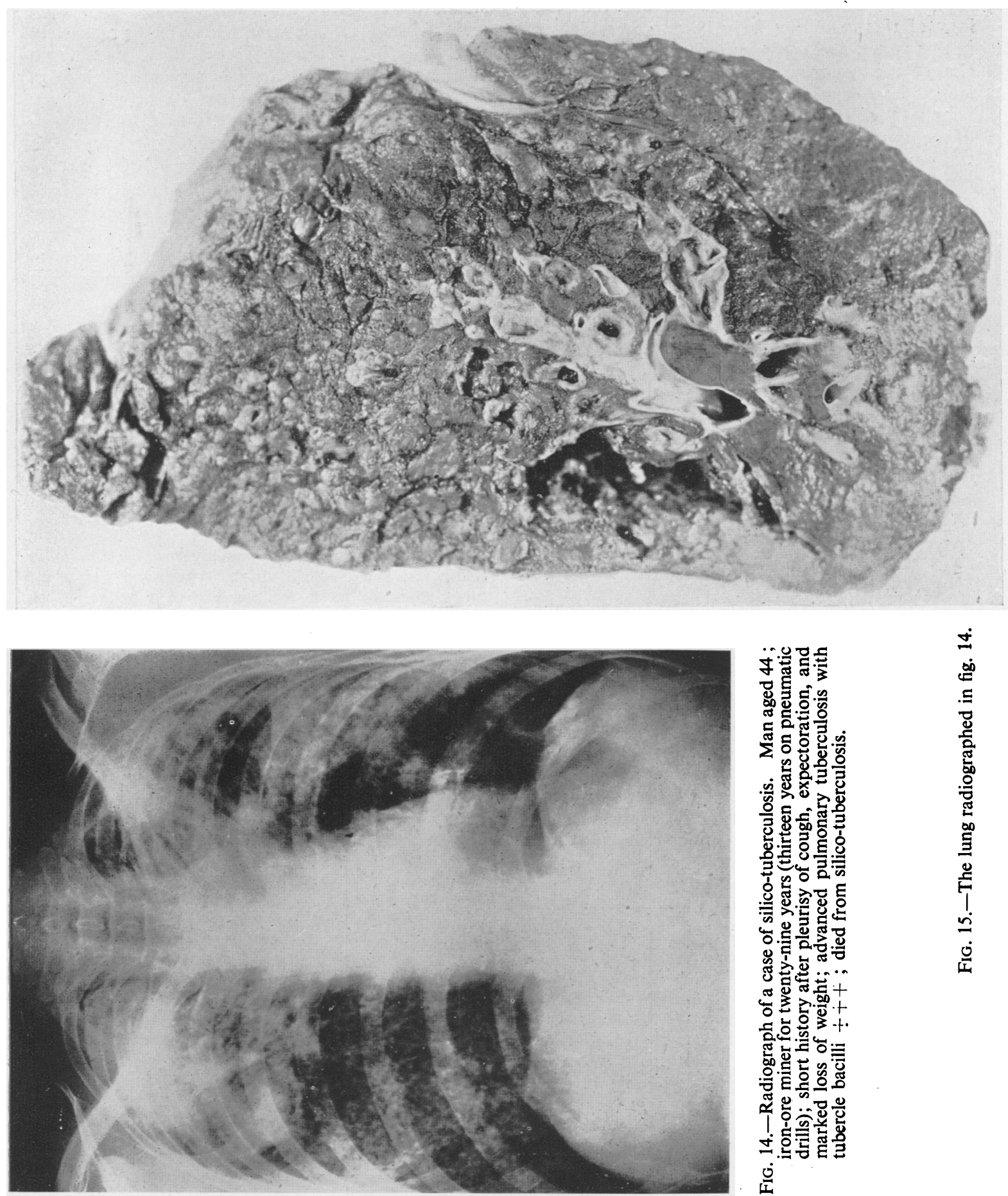

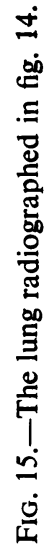


The significance of this change and the pathology of this condition have been discussed earlier in this paper, and it has been demonstrated that the changes are due, in most cases, to the simple accumulation of the inspired dust in the lung alveoli and in the lymphatic channels surrounding the blood vessels of the lung. There is no evidence of mature fibrous tissue, which is the diagnostic feature of the classical type of fibrosis. The radiological appearances are due to dense shadows formed by the intense radioopacity of the particulate haematite.

A detailed and comprehensive study was carried out amongst these men to find out if those with reticulation had been affected physically by the simple accumulation of haematite dust in the lungs. The following is a brief example of the various investigations.

1. Tolerance to exercise.-This simple test was carried out in a series of normal men, and in a series of men with reticulation who were of similar age groups, and the difference was not found to be significant.

2. Total lung volume.-This was performed in the same men to find out if there was any impairment of the lung reserve amongst men with reticulation; in a series of 310 cases no difference in results was found between men who had not been miners or mine workers, and those miners who showed evidence of radiological reticulation.

3. History of shortness of breath.-No significant findings were obtained.

A group of men (84) was similarly examined from a mine in the Furness district. In this mine, the ore is much softer and more easily worked. The chief method of mining is by pneumatic pick, and the amount of explosive used to loosen the ore is consequently much smaller. The age groups were similar to those of the Egremont district group of men, but with a preponderance of older workmen. In the series, 5 men of an average age of 57 years were found to show some radiological changes, rather suggestive of a very early reticular change, but all these men had worked for a number of years in the American copper mines. Of the men who had worked all their life in the Furness district, none showed any evidence of massive shadows, and none showed any evidence of radiographic reticulation.

The difference of the findings for these two districts of Egremont and Furness is significant, as the chemical composition of the ore is very similar, but, as already stated, the physical composition of the two ore-bodies is different, that in the Egremont district being hard and solid, and that in the Furness district softer. In the Egremont district, due to the nature of the ore, dust of very small particulate size is produced by the processes both of drilling and of blasting, whereas the pneumatic picks and smaller explosions in the Furness area probably do not break up the ore mass into such small particles. These facts support the generally accepted theory that the nocuousness of the dust is directly proportionate to the particulate size.

The real proof of the seriousness of a disease cannot be found in statistics of the various types of the condition, but in the number of men who are incapacitated from performing their jobs and from enjoying their lives, and in the number of men who die from the disease. The incidence of deaths from tuberculosis in the haematite industry-as proved by necropsy-is 60 per cent.; and the real death rate may be even higher.

\section{Mining Control}

The new régime dates from 1935 until the present day. New conditions in control, both from the mining and medical point of view, have now been in operation for ten years.

Although attempts had been made from time to time to control dust formation by water, the sprays then in use had never been effective. In fact, conditions were often made worse by increasing the relative humidity of the atmosphere. The essential difference in the Wetherill apparatus was that a vapour mist was formed, and the actual water particles were of minute size. This mist is formed by allowing a trickle of water to enter through a T-piece into a pipe through which is blown compressed air. The result is a very heavy cloud or fog which fills the working place. It was soon found that water itself was only partly effective, as much of the fine dust cloud was left floating in the atmosphere, and the wetting effect on the 'dropped dust' soon evaporated and left conditions bad again as soon as there was any new disturbance to the 'dropped dust.' Thus an agent was required to lower the surface tension of the water globule-and thereby to make them effective in absorbing the small dust particles-and secondly, to make a sticky film on the ' dropped dust ' and so prevent it from being disturbed again. Some oily substance was required, and, after experimental work, castor oil was found to answer the purpose. The oil was contained in a small canister with a supply pipe leading into the compressed air pipe. Fig. 16 shows the apparatus. The proportion of oil to water is about 1 in 100 . The holes are first charged with explosive. The shot firer then lights the fuses, and on the way out he turns on the compressed air, the apparatus being previously fixed in position. After the mist projector has been going for 10 to 15 minutes, the working place is found to be atmospherically clear. At first it was the practice to drop a curtain behind the mist projector to confine the process, but it has been found with experience that conditions are much better without a curtain. Soon after the explosion the dust cloud eddies 
beyond the confines of the mist, but the cool water mist soon lowers the temperature, and the immediate contraction of atmospheric volumes causes a negative pressure, and the dust can be seen to be sucked in and layed by the mist. The mist projector can be seen in operation in figs. 17 and 18 .

\section{Atmospheric Conditions now Prevailing}

In the years before 1935 the atmosphere underground was in a constant state of heavy pollution with haematite dust, and, judged by experiments in reproduced conditions, the number of particles was never less than 4 to 5 millions per c.cm; but with the improved ventilation and precautions the atmosphere now appears healthy. In the early years of the experiment, routine dust counting was performed, and it has been the usual practice to test the places where conditions were likely to be at their worst. Approximately 150 dust counts were made during two years in different.working places in four of the mines.

An Owen's dust counter was used as routine, and the counts were made with dark-ground illumination and with magnification of 1,100 . It is not claimed that the results are accurate, but the results in the series of tests are comparable one with another. The count is a total count, no attempt being made to isolate the silica particles. From estimation of comparable dust in bulk, the amount of silica can be roughly calculated as being less than 10 per cent. on the average. At the same time as the dust sample was taken, wet and dry bulb temperatures were taken and the atmospheric humidity was calculated. Surface temperatures vary from $32^{\circ} \mathrm{F}$. to $69^{\circ} \mathrm{F}$. and surface humidity from 60 per cent. to 93 per cent. The underground temperature did not vary in proportion to the extremes of surface temperature, hardly ever exceeding $70^{\circ} \mathrm{F}$. and maintaining an average

TABLE 2

INCIDENCE OF PULMONARY FIBROSIS AMONGST HAEMATITE MINERS IN WEST CUMBERLAND *

\begin{tabular}{|c|c|c|c|c|c|c|c|c|c|c|c|c|c|c|c|c|}
\hline \multirow{3}{*}{ Year } & \multicolumn{4}{|c|}{ Mine $\mathrm{A} \dagger$} & \multicolumn{4}{|c|}{ Mine B } & \multicolumn{4}{|c|}{ Mine C } & \multicolumn{4}{|c|}{ Mine D } \\
\hline & \multirow{2}{*}{$\begin{array}{c}\text { Cert. } \\
\text { No. }\end{array}$} & \multirow{2}{*}{$\begin{array}{c}\text { Cases } \\
\text { per } \\
\text { cent. }\end{array}$} & \multicolumn{2}{|c|}{ Deaths } & \multirow{2}{*}{$\begin{array}{l}\text { Cert. } \\
\text { No. }\end{array}$} & \multirow{2}{*}{$\begin{array}{c}\text { Cases } \\
\text { per } \\
\text { cent. }\end{array}$} & \multicolumn{2}{|c|}{ Deaths } & \multirow{2}{*}{$\begin{array}{l}\text { Cert. } \\
\text { No. }\end{array}$} & \multirow{2}{*}{$\begin{array}{c}\text { Cases } \\
\text { per } \\
\text { cent. }\end{array}$} & \multicolumn{2}{|c|}{ Deaths } & \multirow{2}{*}{$\begin{array}{c}\text { Cert. } \\
\text { No. }\end{array}$} & \multirow{2}{*}{$\begin{array}{c}\text { Cases } \\
\text { per } \\
\text { cent. }\end{array}$} & \multicolumn{2}{|c|}{ Deaths } \\
\hline & & & No. & $\begin{array}{l}\text { per } \\
\text { cent. }\end{array}$ & & & No. & $\begin{array}{c}\text { per } \\
\text { cent. }\end{array}$ & & & No. & $\begin{array}{c}\text { per } \\
\text { cent. }\end{array}$ & & & No. & $\begin{array}{l}\text { per } \\
\text { cent. }\end{array}$ \\
\hline 1935 & 0 & 0 & 0 & 0 & 3 & 0.7 & 0 & 0 & 1 & 0.3 & 1 & $0 \cdot 3$ & 1 & $0 \cdot 5$ & 0 & 0 \\
\hline 1936 & 3 & 0.7 & 0 & 0 & 11 & $2 \cdot 8$ & 0 & 0 & 0 & 0 & 0 & 0 & 1 & 0.5 & 0 & 0 \\
\hline 1937 & 4 & $1 \cdot 5$ & 3 & $1 \cdot 1$ & 2 & 0.5 & 3 & $0 \cdot 7$ & 4 & $1 \cdot 3$ & 1 & 0.3 & 0 & 0 & 0 & 0 \\
\hline 1938 & 1 & 0.4 & 1 & 0.4 & 0 & 0 & 1 & $0 \cdot 25$ & 1 & $0 \cdot 35$ & 0 & 0 & 0 & 0 & 0 & 0 \\
\hline 1939 & 1 & 0.4 & 1 & 0.4 & 1 & $0 \cdot 25$ & 0 & 0 & 4 & $1 \cdot 5$ & 0 & 0 & 1 & 0.6 & 1 & 0.6 \\
\hline 1940 & 0 & & 3 & 0 & 8 & $1 \cdot 7$ & 2 & 0.4 & 0 & 0 & 1 & $0 \cdot 3$ & 0 & 0 & 2 & 0.9 \\
\hline 1941 & 0 & & 1 & & 3 & 0.6 & 3 & $0 \cdot 6$ & 1 & 0.4 & 1 & 0.4 & 2 & 0.9 & 0 & 0 \\
\hline 1942 & & & & & 0 & 0 & 0 & 0 & 2 & $0 \cdot 8$ & 0 & 0 & 0 & 0 & 0 & 0 \\
\hline 1943 & & & & & 0 & 0 & 1 & 0.2 & 3 & $1 \cdot 1$ & 1 & $0 \cdot 3$ & 1 & $0 \cdot 6$ & 0 & 0 \\
\hline 1944 & & 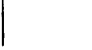 & & & 6 & 1 & 3 & 0.5 & 4 & $1 \cdot 5$ & 1 & 0.3 & 0 & 0 & 1 & 0.6 \\
\hline $\begin{array}{c}\text { Total } \\
\text { No. }\end{array}$ & 9 & & 9 & & 34 & & 13 & & 20 & & 6 & & 6 & & 4 & \\
\hline $\begin{array}{l}\text { Av. In- } \\
\text { cidence }\end{array}$ & & 0.77 & & 0.77 & & 0.68 & & 0.23 & & 0.61 & & $0 \cdot 2$ & & $0 \cdot 36$ & & 0.24 \\
\hline
\end{tabular}

* Results have been calculated from the following data: $(a)$ The number of cases certified as suffering from silicosis (all types) by the Silicosis Board in each year from 1935 to 1944 . The first column shows the actual number of cases occurring in that year, and the second shows the average annual rate in relation to the number of workmen. (b) The number of cases certified by the Silicosis Board as having died from silicosis in the same year periods, with the average decth rate in the second column. A comparable table has been made for each mine. The total number of cases and total number of deaths are also shown for each mine.

+ Mine A was a very old mine and working conditions were very difficult. Ventilation was inefficient and difficult to maintain and (he five years was 0.77 per cent, and all the cases were of advanced silico-tuberculosis. Two years after the closing of the mine, all the cases had died of open tuberculosis. The other mines are more comparable in type and in numbers of men employed. 


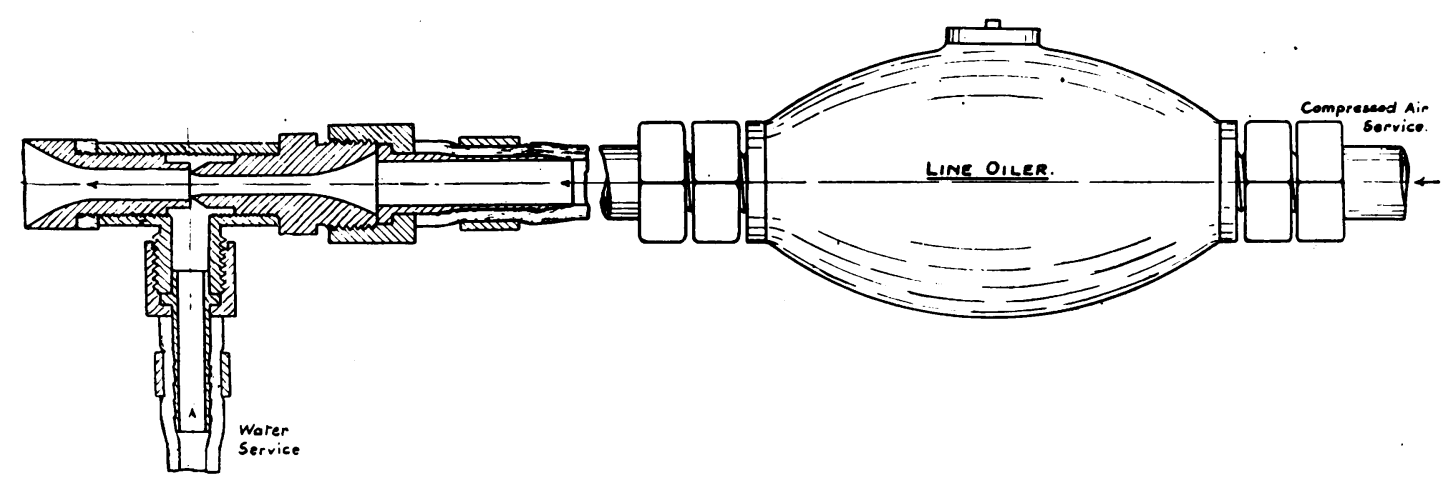

FIG. 16.-Diagram of dust-allaying projector.

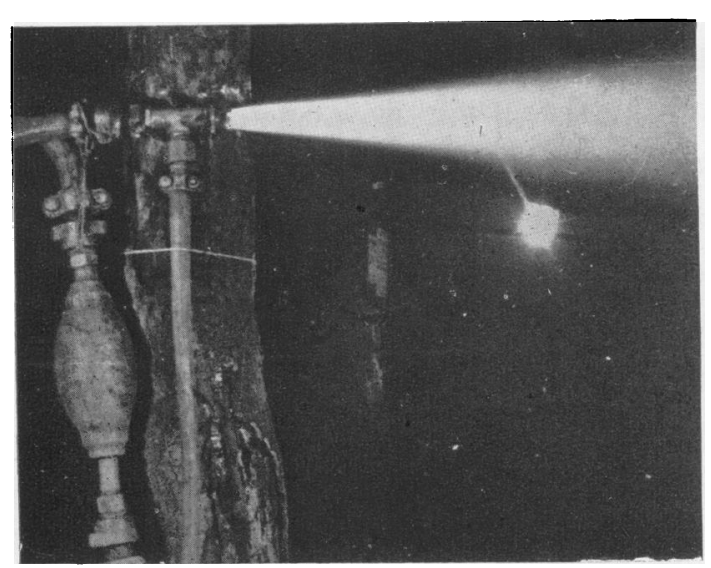

Fig. 17.-Projector in action.

of about $60^{\circ} \mathrm{F}$. Even when the temperature was high in midsummer, it was found that generally the temperature underground was less than that on the surface. This is certainly due to the cooling effect of the water mist. The relative humidity underground was always 90 per cent., because of the constant presence of mist from the sprays. Table 3 shows the average dust concentration associated with the various types of work, and in the various places.

The mean dustiness throughout the working roads is in the region of 2,500 per c.cm., which means that, on an average, the number of particles of silica is 250 per c.cm. Size estimation by graticule shows that 87 per cent. of the particles are less than two microns in size, and this remaining dust is, in the author's opinion, difficult to reduce by any practical means according to our present knowledge. One of the mines was examined after 13 days lying idle, and even then it was found that dust counts in various localities varied from 140 to 210 particles per c.cm. In spite of the fact that there is still an appreciable amount of dust in the mines, it is certain that the actual dust concentration is now only a small fraction of what it was under the old conditions of working. In

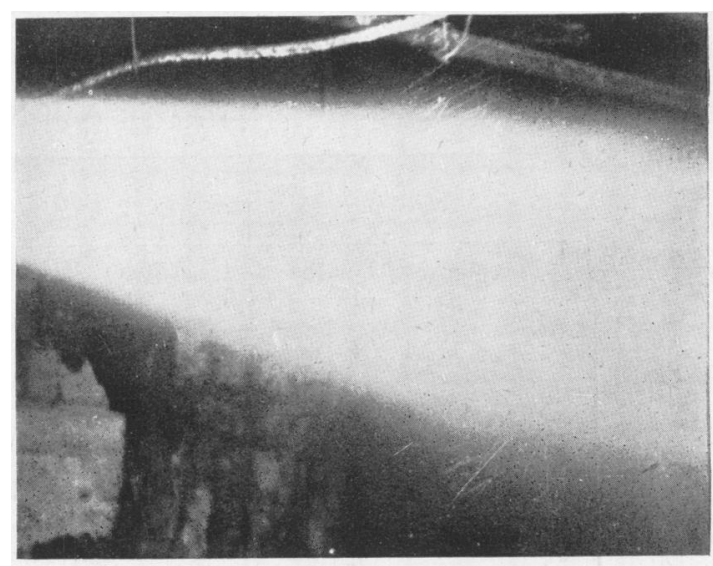

FIG. 18.-Projector in action.

TABLE 3

AVERAGE DUST COUNT IN UNDERGROUND CONDITIONS

\begin{tabular}{|c|c|c|c|}
\hline \multirow{2}{*}{ Location } & \multicolumn{3}{|c|}{ Particles per c.cm. } \\
\hline & $\begin{array}{l}\text { Type of } \\
\text { work }\end{array}$ & $\begin{array}{l}\text { Range of } \\
\text { counts }\end{array}$ & $\begin{array}{l}\text { Mean } \\
\text { count }\end{array}$ \\
\hline $\begin{array}{c}\text { Bottom downcast } \\
\text { shaft } \ldots\end{array}$ & & $0-1,120$ & 420 \\
\hline $\begin{array}{cr}\text { Bottom } & \text { upcast } \\
\text { shaft } \ldots & \ldots\end{array}$ & & $660-6,100$ & 3,030 \\
\hline In solid place $\ldots$ & drilling & $1,782-3,980$ & 2,540 \\
\hline In working end. . & filling & $500-5,910$ & 2,270 \\
\hline $\begin{array}{l}10 \text { minutes after } \\
\text { blast with spray }\end{array}$ & & $2,200-3,920$ & 3,060 \\
\hline
\end{tabular}


addition to the fact that the dust is so much less in amount it is also present in a different form of concentration. Numerous dust particles are bunched in an 'oil water' globule and this conglomeration of particles represents a mass of over 20 microns in size, which is much too large to be inhaled into the lung alveoli. It was thought that, owing to the silica particles being so much lighter than those of haematite, the ratio of silica to haematite would be much higher in the air-borne dust, but samples taken from various baffles of the labyrinth show the ratio to be strictly comparable to the ore being mined in the immediate vicinity.

\section{Medical Control}

As previously stated, ideal medical control necessitates the following conditions:

1. Pre-employment general examination to ensure that a man reaches an excellent general physical standard to fit him for the strenuous physical work that he will be required to perform.

2. Special examination of the lungs to ensure that this system is as perfect as possible. This necessitates a radiological examination.

3. Periodic complete medical examination at selected intervals to ensure that the workman's general condition remains satisfactory, and that his lungs are remaining free from evidence of dust inhalation.

\section{Pre-employment examination}

In pre-war days these examinations were arranged through the mines management, and after the man was found suitable he was referred to the medical clinic. Now arrangements are made through the Ministry of Labour. It is a simple matter to do a routine examination and to say that a man has reached a certain physical standard, but it was soon found that ' a fit man was not necessarily a man fit for the hazards of mining.' During the large-scale examination of men who had worked in the mines, it was soon discovered that men were not all the same physically, and, moreover, it was found that the different types could be classified. In the main, there are two large physical groups (Kretchmer, 1934).

1. Pyknicosomatic.-Generally the man is of small stature and thick set, with short extremities, rounded, well-nourished appearance, and fresh complexion. The skeleton is small, and the fat on face, neck, and trunk is generous. The abdomen is large. The shoulders are narrow, and the chest tends to be barrel-shaped. These appearances become much more apparent in middle age, but the extreme type usually shows the characteristics in the middle twenties. This extreme type has a low lung reserve; in breathing his ribs rise forward in association with abdominal breathing. This group represents only 5 per cent. of the total of this class, yet in table 1 , of the three cases of men who had worked underground less than 10 years and who showed radiographic reticulation, all belonged to this physical category.

2. Leptosomatic.-This is the other large physical group, and the extreme of this group is the asthenic type. They have an angular profile, the shoulders are narrow and sloping, the back is bent forward, and the thorax is round and long. This class represents about 10 per cent. of the male population of this district.

3. Intermediate.-Between these two groups is the large group of mixed types representing 85 per cent. of the male population of this district.

Of 49 consecutive cases with radiological changes who were suffering from shortness of breath of such a degree as to make them unfit for work, table 4 shows the different radiological categories classified according to the physical types of men.

TABLE 4

\begin{tabular}{|c|c|c|c|c|}
\hline $\begin{array}{l}\text { CASES OF CER } \\
\text { ACCORDING }\end{array}$ & $\begin{array}{l}\text { TIFIED } \\
\text { TO }\end{array}$ & $\begin{array}{l}\text { SILICO } \\
\text { HYSICA } \\
\text { JERS }\end{array}$ & IS $\underset{T Y}{C L}$ & $\begin{array}{l}\text { SIFIEI } \\
\text { ES OI }\end{array}$ \\
\hline Type & $\begin{array}{l}\text { Reticu- } \\
\text { lation }\end{array}$ & $\begin{array}{l}\text { Massive } \\
\text { consoli- } \\
\text { dation }\end{array}$ & $\begin{array}{l}\text { Infec- } \\
\text { tive }\end{array}$ & Total \\
\hline Extreme 'Pyknic', & 8 & 6 & 1 & 15 \\
\hline Middle mixed ... & 3 & 7 & 2 & 12 \\
\hline Asthenic & 0 & 7 & 15 & 22 \\
\hline
\end{tabular}

These findings suggest that the extreme pathological changes due to the inhalation of haematite iron ore dust occur predominately in the two extreme physical types of men, and, in consequence, these extreme types are not accepted for underground work.

Tuberculosis.-In choosing new workmen who have not been in mining before, and this includes a large number of youths between the ages of 14 and 18 , other conditions are often found which necessitate rejection, and the commonest single condition is tuberculosis. Of 883 recruits between 14 and 40 years of age who have been examined radiologically during the last nine years, $4(0.45$ per cent.) had active pulmonary tuberculosis, and $5(0.56$ per cent.) had inactive pulmonary tuberculosis. (The incidence amongst men with previous mining experience was much higher-see table 1.) Of the total, 883, 133 were rejected for other conditions, including history of past illness - especially pulmonary-and failure to reach the requisite physical standard. Thus, 15 per cent. of entrants were rejected. Amongst men with mining experience a 
much higher number was rejected, only 60 per cent. being accepted.

Very careful notes are taken at the pre-employment examination, and these are recorded on a medical card which is retained in a card index, the $x$-ray film is filed in a similar manner. The reverse of the card provides space for the records of follow-up examinations; thus as the years go on a serial record is obtained of new illnesses, the type of work that the man has been performing, his height, weight, $x$-ray findings, pulmonary capacity, etc. It was decided that a yearly examination should be carried out on each man, and this was done until the second year of the war, when travelling became too difficult. But during the last few months the former routine has been resumed, and arrears of examinations are being made up.

Disposal of Rejected Men.-Of the total number of men rejected, 98 per cent. are medically fit, and the only reason for rejection is that they are not considered fit for an industry that has a silicosis risk. A note is made of those who have active tuberculosis, or who have had tuberculosis which has become healed, and a full note, with the $x$-ray film, is sent to the family doctor. These cases are either notified and treated, or kept under observation by the tuberculosis authority.

After 10 years 56 per cent. of the underground population in these mines are picked men who have been chosen carefully and are known to be in good health and with no radiological evidence of haematite accumulation in their lungs. They are also known not to be suffering from tuberculosis. Of the underground population under 40 years of age, 69 per cent. are picked men. The percentage of ' new miners' in each age group of underground workers is as follows: under 20,100 per cent.; 20 to 29,89 per cent.; 30 to 39,59 per cent.; 40 to 49, 39 per cent.; $50+, 20$ per cent. It is estimated that in another 10 years, with a normal intake of new men, 100 per cent. of the age group 20-30 will be chosen men, and almost 70 per cent. of the entire underground population will be ' new miners.' Of workmen under 40 years of age employed in the haematite mining industry, the death rate from pulmonary tuberculosis is now nil.

\section{Results of Mining and Medical Control}

As it is now 10 years since the institution of ' new miners' and new methods of dust control in the Egremont area, it is possible to draw some conclusions as to the effectiveness of the control methods. It is proposed to consider only the men who began work underground during the years
1935,1936 , and 1937 , as this ensures that the men have had an average of over 8 years as underground workers. Some of the 411 men who were accepted during these years have been on surface work, so they were not taken into account for this study. There has also been a large wastage from men going to other work or joining the Forces. The number of men is thus only 66 , but they have all had experience of actual machine work.

Table 5 shows in the first column the 49 miners examined who worked in the old conditions with less than 10 years' experience underground. This is the same as in table 1. In the second column is shown the result of examination of the total number of ' new miners' with from 8 to 10 years' experience underground in the new conditions of mining and medical supervision.

\section{TABLE 5}

COMPARISON OF INCIDENCE OF RADIOLOGICAL CHANGES BETWEEN UNSELECTED MINERS IN OLD WORKING CONDITIONS AND SELECTED MINERS IN NEW WORKING CONDITIONS.

\begin{tabular}{|c|c|c|c|}
\hline & \multicolumn{2}{|c|}{\begin{tabular}{|} 
Men under old \\
conditions \\
(less than 10 years under- \\
ground)
\end{tabular}} & \multirow[t]{2}{*}{$\begin{array}{l}\text { New } \\
\text { miners } \\
\text { ( } 8 \text { to } 10 \\
\text { years } \\
\text { under- } \\
\text { ground) }\end{array}$} \\
\hline & & $\%$ & \\
\hline Normal radiograph & 44 & $89 \cdot 6$ & $66100 \%$ \\
\hline Reticulation & 3 & $6 \cdot 2$ & 0 \\
\hline Nodulation & 0 & 0 & 0 \\
\hline Consolidation & 0 & 0 & $\mathbf{0}$ \\
\hline Other lesions & 2 & $4 \cdot 2$ & 0 \\
\hline Total & 49 & 100 & 66 \\
\hline Average age & 28 & & 27 \\
\hline $\begin{array}{l}\text { Average years under- } \\
\text { ground }\end{array}$ & $5 \cdot 4$ & & $8 \cdot 3$ \\
\hline $\begin{array}{cc}\text { Average years } & \text { on } \\
\text { machines } & \ldots\end{array}$ & 0 & & 3 \\
\hline
\end{tabular}

The new series shows that there has been no radiological change in the lungs of any of these men, the condition being exactly as it was 8 or 9 years ago. Thus at the present time it appears that 100 per cent. success has been achieved. It was hoped to be able to do a complete medical survey of the mines, but this has been impossible to achieve for many 
reasons. It has been possible, however, to examine 39 men who had been employed underground for from 20 to 30 years. These were all men who had worked underground until the day of examination and who were either being examined for some other reason, or who were being transferred from one mine to another. These men had not been examined before their original employment, and were, therefore, not physically picked men, but they had worked for almost half of their time in the new conditions of mining. Table 6 shows in the first columns the miners working under the old régime, and the second group are those who have worked for almost half their underground working life in the new conditions. Although the number in each group is small, the groups are comparable in numbers, average age, and average number of years worked underground, and each is an unselected sample.

Since the inclusion of this industry in the Silicosis Compensation Acts, the men have become 'silicosis minded,' and for some years the occupation of iron ore miners has not been a popular one. The men began by mistrusting the compulsory pre-employment medical examination, as they thought that the sole idea of the owners was to get rid of their obligations. Now that the men are realizing that the system is for their own good they are becoming reassured. It has now been possible to inform these new miners that 10 years' work underground has had no deleterious effect on their lungs, and it has been possible to convince them that they have actually improved physically.

\section{Discussion on Pneumoconiosis due to Mixed Haematite Dust}

From our present knowledge of the condition, it is agreed that industrial pulmonary fibrosis is due to particulate silicon dioxide $\left(\mathrm{SiO}_{2}\right)$, and it must be inhaled in particles smaller than 5 microns in order to reach the lungs and cause an injurious reaction. The purer the silica the more closely does the reaction in the lung approach the classical type as exemplified in the South African Gold Field. In the case of haematite mining the reaction is in most cases very mild and very slow, and in "radiological reticulation' the dust is practically lying inert, with none-or a very minimal-reaction in the host lung, the radio-opacity of the haematite iron ore giving the dense radiological picture. Experiments by Kettle (1932) proved that iron alone causes no reaction; in fact, by coating silica with iron he could prevent any reaction in the lung from occurring, and Carleton (1927), using haematite, was quite unable to demonstrate any fibrous reaction in the lungs of rabbits. The conclusion to be drawn from these findings is that the admixture of an inert dust retards or inhibits the reaction of silica and this has been proved by the brilliant work of Briscoe and others (1937). Attempts have been made in this clinic to confirm this work, and it was found that

TABLE 6

COMPARISON OF INCIDENCE OF RADIOLOGICAL CHANGES IN MINERS WHO HAVE WORKED ONLY UNDER OLD WORKING CONDITIONS AND SELECTED MINERS IN NEW WORKING CONDITIONS

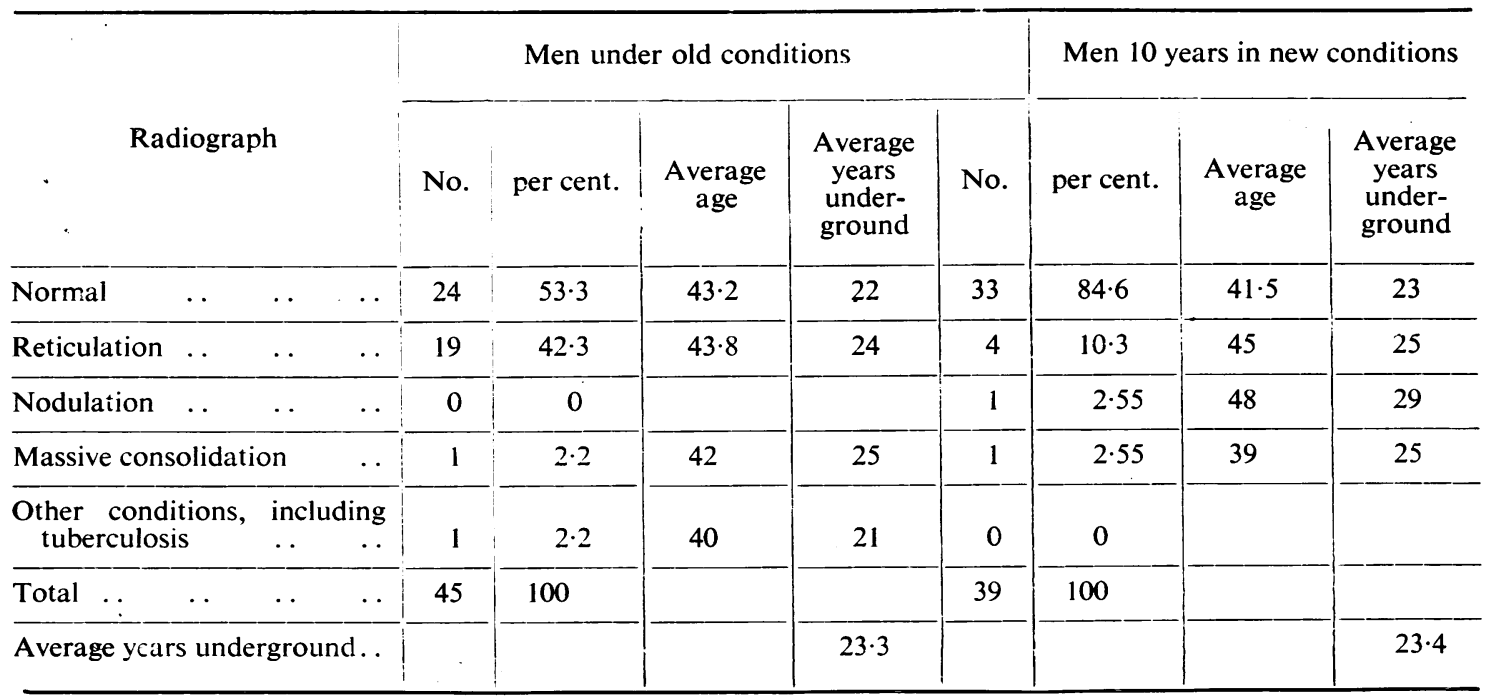


TABLE 7

SILICA AND IRON CONTENT OF LUNGS OF IRON ORE MINERS ACCORDING TO PATHOLOGICAL CLASSIFICATION (NUMBER OF CASES IN BRACKETS)

\begin{tabular}{|c|c|c|c|c|c|c|c|c|c|c|}
\hline \multirow{2}{*}{ Pathological classification } & \multirow{2}{*}{ Age } & \multirow{2}{*}{$\begin{array}{l}\text { Years } \\
\text { under- } \\
\text { ground }\end{array}$} & \multicolumn{2}{|c|}{$\begin{array}{l}\text { Percentage } \\
\text { silica to }\end{array}$} & \multirow{2}{*}{$\begin{array}{l}\text { Total } \\
\text { silica }\end{array}$} & \multicolumn{2}{|c|}{$\begin{array}{l}\text { Percentage } \\
\text { Fe to }\end{array}$} & \multirow{2}{*}{$\begin{array}{c}\text { Total } \\
\mathrm{Fe}\end{array}$} & \multirow{2}{*}{$\begin{array}{l}\text { Percentage } \\
\text { Ash }\end{array}$} & \multirow{2}{*}{$\begin{array}{l}\text { Ratio } \\
\mathrm{Si} / \mathrm{Fe}\end{array}$} \\
\hline & & & Lung & Ash & & Lung & Ash & & & \\
\hline Reticulation (14) & 58 & 37 & $1 \cdot 42$ & $8 \cdot 3$ & $3 \cdot 58$ & $9 \cdot 8$ & 49 & $23 \cdot 5$ & $19 \cdot 7$ & $1 / 7 \cdot 5$ \\
\hline Nodulation (6) & 57 & 29 & 0.96 & $6 \cdot 0$ & $2 \cdot 21$ & $7 \cdot 2$ & 45 & $21 \cdot 3$ & $14 \cdot 6$ & \\
\hline Massive fibrosis (12) & 57 & 40 & $1 \cdot 7$ & $8 \cdot 1$ & $6 \cdot 3$ & $10 \cdot 3$ & 47 & $47 \cdot 5$ & $21 \cdot 4$ & $1 / 6$ \\
\hline $\begin{array}{cc}\text { Massive fibrosis and open } \\
\text { tuberculosis (30) }\end{array}$ & 56 & 33 & $1 \cdot 4$ & $8 \cdot 9$ & $5 \cdot 7$ & $6 \cdot 6$ & 42 & $27 \cdot 3$ & $15 \cdot 7$ & $1 / 4 \cdot 5$ \\
\hline Tuberculosis alone (6) & 32 & 16 & $0 \cdot 16$ & $2 \cdot 8$ & 0.96 & 0.52 & $8 \cdot 6$ & 3.9 & $5 \cdot 6$ & $1 / 3 \cdot 9$ \\
\hline
\end{tabular}

with haematite dust containing 8 per cent. $\mathrm{SiO}_{2}$ the solubility of the silica was markedly depressed. In spite of the fact that haematite is known to retard the action of silica in the human lung, it has been abundantly proved that pulmonary fibrosis has occurred in the past; and, in fact, we are still seeing cases at the present time, although these cases certainly developed the condition while working under the conditions of mining that were prevalent before 1935. Is it possible to say what is the causal factor, and is only one cause responsible?

\section{The Rôle of Silica}

An exceilent opportunity has been presented by a large-scale review of necropsy material. During the last 10 years 78 necropsies have been performed by Dr. Faulds, pathologist to the Cumberland Infirmary, on haematite miners who were known or suspected to have died of silicosis. A chemical analysis has been done on these lungs by Dr. Faulds and he has kindly allowed me to use his results. The silica and iron content has been estimated, and the results are shown in Table 7 under the varying radiological classifications confirmed at post-mortem examinations.

The age and the average number of years spent underground is strictly comparable for each group.

Percentage Silica to Lung.-These figures show no significant difference when comparing the various pathological groups, and it is worthy of note that nodulation, which is a stage advanced from reticulation, shows a lower percentage of silica; the percentage silica to ash compares closely in ratio to the previous column.

Total Silica.-Here we have a significant change in the amount of silica present in lungs showing massive fibrosis, and massive fibrosis with tuberculosis, when compared to those showing reticulation and nodulation. Is this difference due to the original presence of more silica in the lungs or is there some other factor operating?

Tuberculosis.-It has been shown both anatomically and chemically that these lungs contain large quantities of haematite, and as much silica as is usually present in ordinary cases of silicosis. Yet $x$-ray reticulation shows no fibrosis, although the amount of silica is quite adequate to produce actual silicosis. Tuberculosis is one obvious factor, and in cases of massive fibrosis without obvious tuberculosis, some evidence of very old and long-standing tuberculosis can often be found, and the large total silica and haematite content of these lungs is probably due to their being anchored in the lungs by the inflammatory fibrotic processes (probably almost always tuberculosis).

The coalescent or massive fibrosis is usually described as a merging together of discreet small nodules to form a new large mass, but in haematite fibrosis the large mass is certainly not formed in this way but always by a new inflammatory condition being superimposed, and the resulting masses are a direct outcome of the new process which in the large majority of cases is tuberculous.

A warning should be given about over-enthusiasm in the use of aluminium either in a preventive or curative capacity. Aluminium is in itself alleged to be innocuous; haematite also is innocuous. Aluminium depresses the solubility of silica, as does haematite; but in spite of these facts, it must be remembered that test-tube results cannot be applied to the human lung, and even the findings in animal experiments cannot be applied to human beings. 
Too much reliance may be placed on these highly artificial methods, when it is only after a time-lag of 20 years that the effectiveness or otherwise of such a method can be truly assessed.

\section{Conclusions}

This paper has formulated the methods, both medical and engineering, for the control of pneumoconiosis in the haematite mining industry in West Cumberland, but this is only part of a general service to improve the lot of the worker in these mines; to make him a better and happier workman, and to permit him to enjoy his work and leisure in comfort and good health. Such a service has now been functioning for more than 10 years, and the results are indeed heartening, but it is only as a result of constant vigilance from the mining and medical point of view that the plan can operate efficiently. The human element and its full understanding is by no means the least of the problems.

The mist projector is almost useless if it is not used efficiently, and it is found that three main reasons operate constantly in attempting to cancel out the benefits.

1. The enthusiasm of the hard-working miner tends to make him re-enter the working place much too soon, and before the spray has had enough time to do its work.

2. The laziness of some workmen make them just ' not bother' and so they jeopardize not only their own future good health but that of their fellows.

3. Familiarity breeds contempt and with it carelessness.

The answer to these questions is an efficient and understanding management, and in this matter it has been the good fortune of the controllers of these experiments to have had men who have known the old conditions, and the miseries and discomforts that have been a relic of these conditions. This knowledge has been a driving force in improving conditions and maintaining them, but it is because of the long time-lag before the good results of dust suppression are seen that the greatest care must be taken in maintaining the enthusiasm of the workmen.

A final word must be said about the mutual respect and trust between the medical officer and the management on the one hand, and the workmen on the other. From the medical point of view the relationship of doctor and patient must be maintained inviolate. If the medical officer finds, during a routine examination, that there is some deviation from the normal health, whether it be from an occupational or other cause, his duty must primarily be to the patient, who has an absolute right to an explanation of the reason for the medical officer's opinion. It may be that, in the future, cases will be found who show early evidence of dust inhalation, and it is the object of this organization to take such a man away from risk and provide for him some other means of earning a living, and there must be no prejudice against the workmen. It is to be hoped that such a necessity will not arise, but ways and means should be found for the just disposal of such a case.

\section{Summary}

1. The haematite deposits are in two locations, north and south. The north mines produce pulmonary fibrosis, the south do not.

2. The disease has probably been prevalent for at least 40 years, i.e. before the advent of pneumatic drills.

3. Uncomplicated pneumoconiosis or radiological reticulation is not, of itself, an incapacitating condition. The single incapacitating and death-causing factor is infection, usually tuberculosis.

4. The condition of dustiness in the West Cumberland mines before 1935 was intense, many millions of particles per c.cm. A new regime was introduced in 1935 . Dust allaying by the mist projector has diminished the dust content of the air to an average of 2,500 particles per c.cm., i.e. approximately 250 particles of silica per c.cm. A complete medical service selects only fit men for work. Workmen are radiographed before admission and periodically thereafter. The results of engineering and medical control has resulted, after a 10-year period of trial, in 100 per cent. success.

5. Although it is too soon to predict, it is suggested that silicosis will probably cease to be a problem if the incidence of tuberculosis is strictly controlled and eventually eradicated.

\section{REFERENCES}

Briscoe, H. V. A., Mathews, J. W., Holt, P. F., and Sanderson, P. M. (1937). Trans, inst. Min. Metall, Lond., 46, 145.

Carleton, H. M. (1927). J. Hyg., Camb., 26, 227.

Collis, E. L. (1923). Proc. roy. Soc. Med., 16 (Sect. of Epidemiology and State Medicine), 85

Crond Goadby, Sir K. W. (1930). J. industr. Hyg., 9, 266.

Cronin, A. J. (1926). Ibid., 8, 291.

Fell, A. (1908). "The Early History of Furness."

Hart, P. D., Aslett, A. E., and others. (1942). Chronic Pulmonary Disease in South Wales Ccal Miners. 1. Medical Studies. M.R.C. Spce. Rpt. No. 243. London.

Kendall, J. R. (1893). "The Iron Ores of Great Britain and Ireland." Kettle, E. H. (1932). J. Path. Bact., 35, 395.

Kretchmer, E. (1934). "A Textbook of Medical Psychology." Trans. Strauss, E. B. Oxford University Press. London.

Smith, B. (1924). Special Reports on the Mineral Resources of Great Britain. Vol. VIII, Iron Ores: Hematite of West Cumberland, Lancashire and the Lake District. 2nd ed. London. 